Article

\title{
The Trend in the Risk of Flash Flood Hazards with Regional Development in the Guanshan River Basin, China
}

\author{
Ningyue Chen ${ }^{\mathbb{D}}$, Yanjun Zhang * ${ }^{\mathbb{D}}$, Jinjin Wu, Wenxun Dong $\mathbb{D}^{\mathbb{D}}$, Yixuan Zou and Xin Xu \\ State Key Laboratory of Water Resources and Hydropower Engineering Science, Wuhan University, \\ Wuhan 430072, China; chenningyue@whu.edu.cn (N.C.); wujinjin@whu.edu.cn (J.W.); \\ dongwenxun@whu.edu.cn (W.D.); zouyixuan@whu.edu.cn (Y.Z.); xuxin0225@whu.edu.cn (X.X.) \\ * Correspondence: zhangyj1015@whu.edu.cn
}

Received: 16 May 2020; Accepted: 22 June 2020; Published: 24 June 2020

\begin{abstract}
The economic development of China's mountainous areas has been rapid, but the impact of flash floods is often ignored during regional development planning. Therefore, a method needed to be developed to simulate flash flood disasters and analyze the trends in flash flood disasters with regional development. Taking Guanshan River Basin as the research area, we combined the digital elevation model (DEM) with the inflow hydrograph, using the topography-based hydrological model (TOPMODEL). Verified by historical flash flood disasters, the watershed model was built based on the finite volume conservation flood routing model (FLO-2D). Then, we simulated the hazard distribution of flash flood disasters, developed a risk status assessment factor (RSAF) for flash flood disasters and calculated the increased ratio from 2003 to 2018. The results show that in 2003, the total hazard area of flash flood disasters affecting human settlements was $61,121 \mathrm{~m}^{2}$, which increased to $118,404 \mathrm{~m}^{2}$ in 2018. Since 2003, with the development of the regional economy, more residents moved to risk and extreme risk zones; thus, the risk of flash flood disasters also increased. Due to the significant damage caused by the flash flood on 5 August 2012, some of the local residents moved away from the high risk and extreme risk zones, indicating that the risk trend of flash flood hazard was consistent with the regional development of Guanshan River. We provide suggestions for regional economic development planning; the risk assessment for flash flood disasters must be considered to ensure the stable development of the regional economy, and using the RSAF would be efficient.
\end{abstract}

Keywords: Guanshan River; flash flood; FLO-2D; hazard distribution; regional development

\section{Introduction}

Flash floods have serious social and economic impacts and destroy people's lives, houses, and social networks [1]. Generally, floodable areas are near rivers, which are often water resources for domestic, agricultural, and industrial purposes, such as the Nile River Basin [2]. Therefore, humans often live in floodable areas due to the better living condition. However, once flood disasters occur, huge losses ensue. For example, in late September 2000, a devastating flood struck Gangetic West Bengal, India, having severe impacts on rural settlements [3]. In September 2002, a storm triggered a series of flash floods on the Gard River in the south of France [4].

To mitigate the risk of flash flood disasters as much as possible, scholars around the world have conducted a series of studies. Špitalar et al. [5] selected 12 of the largest flash floods in the conterminous United States, to conduct an integrated analysis of temporal and spatial flash flood parameters and human impacts, and found that in flash flood events, humans are mostly impacted by short flood durations, small catchment sizes in rural areas, vehicles, and nocturnal events with low visibility. 
To better understand the mechanism of storm-induced flash floods, Ruin et al. [6] first attempted to combine an analysis of the physical and human response to Mediterranean storms, and found that coherence between the time and location of the reported fatalities and the hydrometeorological conditions is strong. Through the analysis of flood disasters, Jiang et al. [7] found that before the mid-1980s, the flash flood disasters in Xinjiang, China, were mainly caused by local human activities; after the mid-1980s, they were mainly caused by abnormal precipitation. These studies provide theoretical support for avoiding flash flood risks.

With regional development in hilly areas, human activities have become more concentrated, and the distribution of towns and major construction projects in river valleys has become denser. Densely populated areas, the locations of economically dense areas, and flood hazard areas often coincide, exacerbating the potential damage of flash flood disasters [8]. Because flash flood disasters are closely related to human activities, most scholars consider population distribution factors in the risk distribution of flash flood disasters. Forkuo [9] demonstrated the use of a geographic information system (GIS) technique with different data related to land use and population densities to develop a hydrological model which depicts a flood hazard index map, in which hazard indices are assigned for population density, proximity, and frequency of flood inundation, over a period that informed the authorities about resource allocation, evacuation practices, and other mitigation options to adopt in the event of a flood. Therefore, the risk of flash flood disaster must be analyzed in combination with human-related data, such as population, houses, and field changes.

Given human activities, the risk trend of flash flood hazards must be considered in regional development planning of mountain areas. Garrote et al. [10] reported the results obtained from the application of different magnitude-damage functions in a small mountain town and estimated the direct economic losses caused by the occurrence of flash floods with different return periods. Vojtek and Vojteková [11] combined hazard maps with the current and planned urbanization extent and made a decision about the accepted level of risk. These studies showed that the risk of flood disasters must be considered in regional economic development planning. However, studying the effect of regional flood disasters in time series is difficult. If a factor could be introduced to intuitively assess the risk status of flash flood disasters with the regional development in different years, the risk trend of flash floods could be obtained, which would help guide people to avoid risks and reduce economic losses, which would be helpful for the long-term development of the regional economy.

Based on historical flood disasters, we used a topography-based hydrological model (TOPMODEL) to simulate the inflow hydrograph, combined with digital elevation model (DEM) to develop a watershed model based on finite volume conservation flood routing model (FLO-2D). With this method, we simulated flood disasters with different frequencies and analyzed flood intensity to map the hazard distribution of flash flood disasters considering human settlements. To further evaluate the risk status of flash flood disasters and determine the relationship between flash flood disasters and regional development in the Guanshan River Basin, we developed the risk status assessment factor (RSAF) for flash flood disasters and compared the risk status of flash flood disasters in 2003, 2013, and 2018, by calculating the increased ratios, providing suggestions for regional economic development planning.

\section{Study Area and Data}

\subsection{Study Area}

We selected the Guanshan River Basin, the tributary of the Danjiangkou Reservoir, as the research area. The average slope of the main stream of the Guanshan River is $5.7 \%$, the drainage area is $465 \mathrm{~km}^{2}$, and the average annual flow is $7.78 \mathrm{~m}^{3} / \mathrm{s}$. The length of the river is $14.2 \mathrm{~km}$, and the river network density is about $0.84 \mathrm{~km} / \mathrm{km}^{2}$. The average annual precipitation is $1100 \mathrm{~mm}$. The terrain is dominated by hills and small to medium-sized rolling hills. The elevation is 153-1634 $\mathrm{m}$ above sea level (a.s.1.) and the average elevation is $690 \mathrm{~m}$ a.s.l. [12] The location of the Guanshan River Basin is shown in Figure 1. 


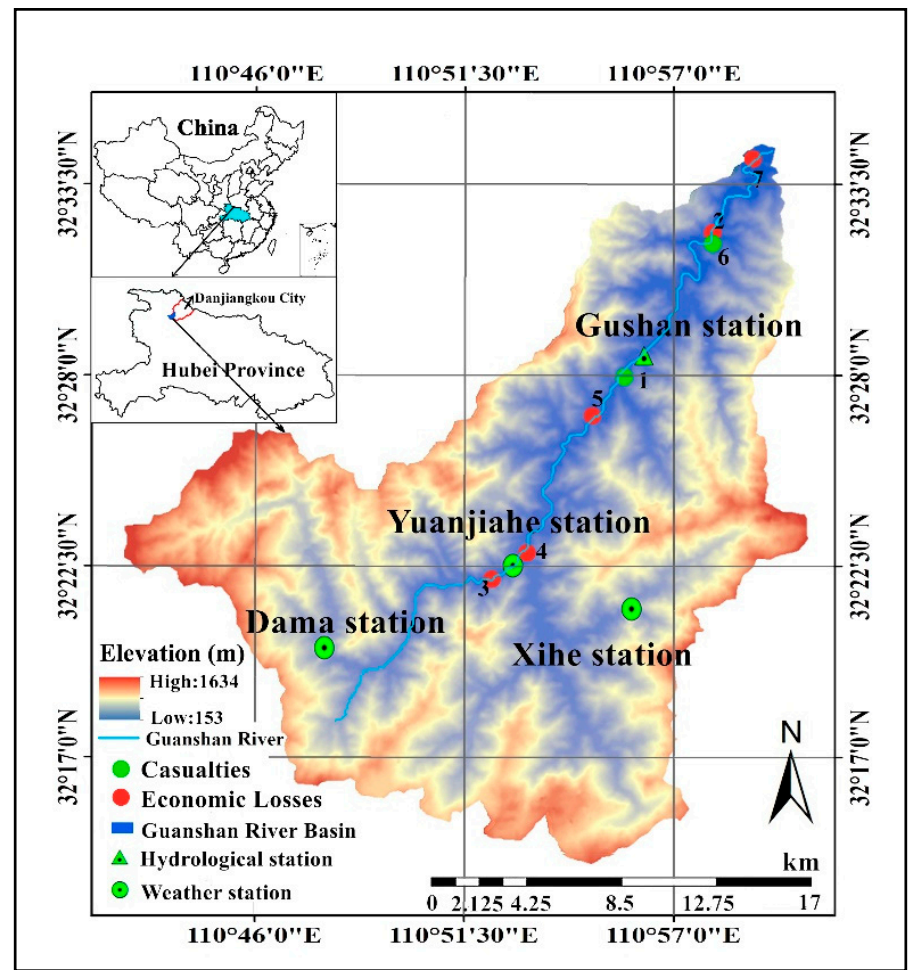

Figure 1. Location of Guanshan River Basin and hazard distribution of the catastrophic flash flood disaster on 5 August 2012.

The Guanshan River Basin, located in a rainy area in the Hubei and Henan provinces, is an area with high-incidence local rainstorms. Historically, the area has experienced two disastrous flood events, in 1935 and 1975. The area also frequently experiences the flash flood, mudslide and landslide disasters. On 5 August 2012, a severe flood disaster occurred that caused great harm, as shown in Figure 2. Because the maximum discharge occurred on 6 August 2012, it is also called No. 20120806 flood. The Gushan Hydrological Station in Guanshan measured the rainfall as reaching $287 \mathrm{~mm}$ in $28 \mathrm{~h}$ from 11:00 p.m. on 4 August to 3:00 a.m. on 6 August, resulting in flooding in the town. Three people died in this flash flood. All the power supply, transportation, communication, and water supply to the 13 villages in Guanshan were interrupted, and the damage to the houses and farmland was serious. More than $50 \%$ of houses and almost all the farmlands were flooded. The whole department of highway management in Shifang was destroyed. The disaster, which affected 13 villages, resulted in three casualties, and direct economic losses of up to more than RMB 23 million (about $\$ 3.22$ million) [13].
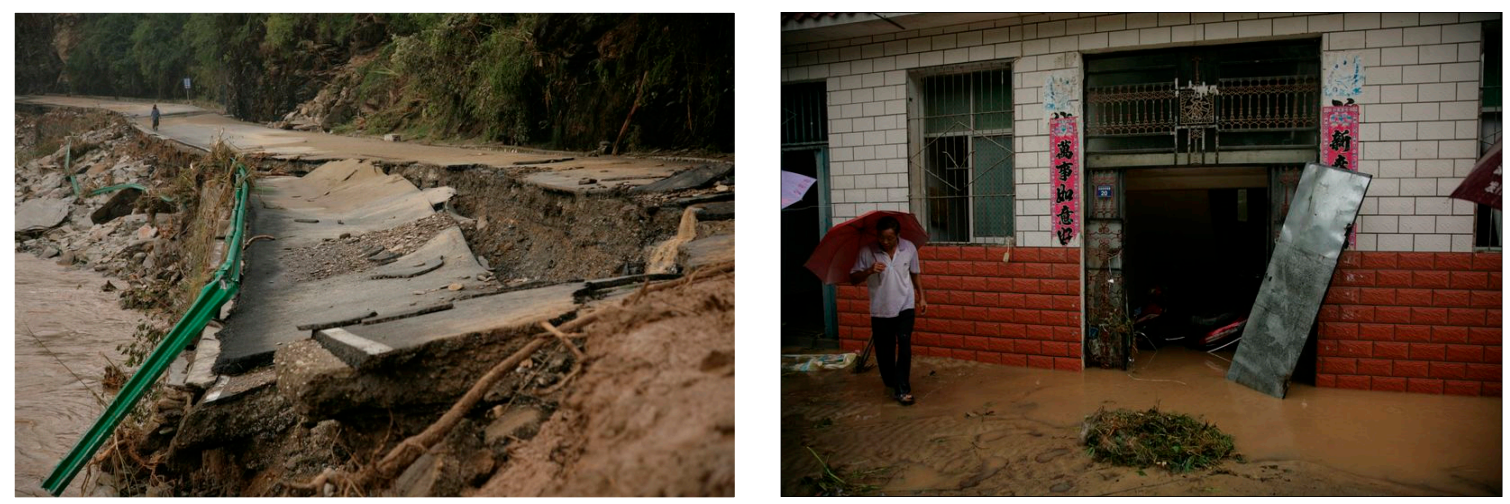

Figure 2. Severe flash flood disaster in the Guanshan River Basin on 5 August 2012 [14]. 
As the flash flood disaster that happened on 5 August 2012 was the most severe flood in recent years, a field survey in the Guanshan River Basin was conducted. The investigation revealed seven representative accident points, which mainly included the loss of submerged houses and casualties. The geographic locations are shown as Points 1 to 7 in Figure 1. The disaster situation, measured maximum flow depth, and disaster degree of seven accident points are described in Table 1.

Table 1. Investigation results of flash flood disaster on 5 August 2012.

\begin{tabular}{cccc}
\hline Accident Positions & $\begin{array}{c}\text { Measured Max Low } \\
\text { Depth }(\mathbf{m})\end{array}$ & Disaster Situation & Disaster Degree \\
\hline 1 & 4.94 & House flooded about 6 m; two deaths & Extreme Risk \\
2 & 5.09 & A department of highway management & Extreme Risk \\
3 & 3.55 & was destroyed; one death & High Risk \\
4 & 4.35 & Water submerged to the bridge arch & Extreme Risk \\
5 & 4.06 & House flooded about $1.2 \mathrm{~m}$ & Extreme Risk \\
6 & 5.38 & House flooded about $0.8 \mathrm{~m}$ & Extreme Risk \\
7 & 1.27 & House flooded & Risk \\
\hline
\end{tabular}

\subsection{Data}

We obtained hydrological data, including discharge data and rainfall data. The discharge data of the Guanshan River Basin were collected from the Gushan Hydrological Station, which was built in 1973. We obtained 22 years of measured discharge data from 1973 to 1987 and 2009 to 2015, including daily and some hourly discharge data. The rainfall data of Guanshan River Basin were obtained from Gushan Hydrological Station and three weather stations, Dama Station, Xi Station, and Yuanjiahe Station, including daily, some hourly, and minute rainfall data from 1973 to 1987 and 2009 to 2015.

The terrain data used in this study were mainly obtained from data recorded by a drone. The type of the used drone was a DJI Phantom 4 Pro (SZ DJI Technology Co., Ltd., Shenzhen, Guangdong province, China). The photos taken by the drone were processed by Agisoft PhotoScan software (Agisoft LLC, St. Petersburg, Russia), and the DEM data of Guanshan River Basin were obtained using inverse distance weighted interpolation, with a resolution of $0.1 \mathrm{~m}$. The main process for obtaining DEM data included adding chunk and photos into chunk, aligning photos, optimizing cameras, building a dense cloud, meshes, texture, tiled model, and DEM, and then exporting DEM [15]. In this study, due to the large area of the Guanshan River Basin, a DEM with a resolution of $10 \mathrm{~m}$ was selected for better simulation. Using an inverse distance weighted interpolation, a DEM with a resolution of $10 \mathrm{~m}$ was obtained. The average error of $10 \mathrm{~m}$ DEM is $0.24 \mathrm{~m}$.

Population census data from 2003 to 2018 in Guanshan town were obtained from the China Statistical Yearbook (Township) [16]. The distribution of houses and fields were obtained through Google Earth (Google, Mountain View, CA, USA).

\section{Methods}

To assess the risk status of flash flood disasters, firstly, a hydrological model was used to generate the inflow hydrograph of designed flood. Secondly, to simulate maximum flow depth, velocity, and impact force, a suitable hydrodynamic model was chosen. In this study, TOPMODEL and FLO-2D were used for hydrological and hydrodynamic simulations, respectively. Based on the results of the simulations, the flood intensity was calculated. Thirdly, in combination with the selected flood frequency, the hazard level was calculated. Fourthly, according to the human settlements in different years, the hazard map of flash flood disasters in human settlements was obtained. Finally, the statistics of the area of different hazard levels were calculated, and the proposed RSAF and increased ratio were used to assess risk status of flash flood disasters in different years. The methodological flowchart is shown in Figure 3. 


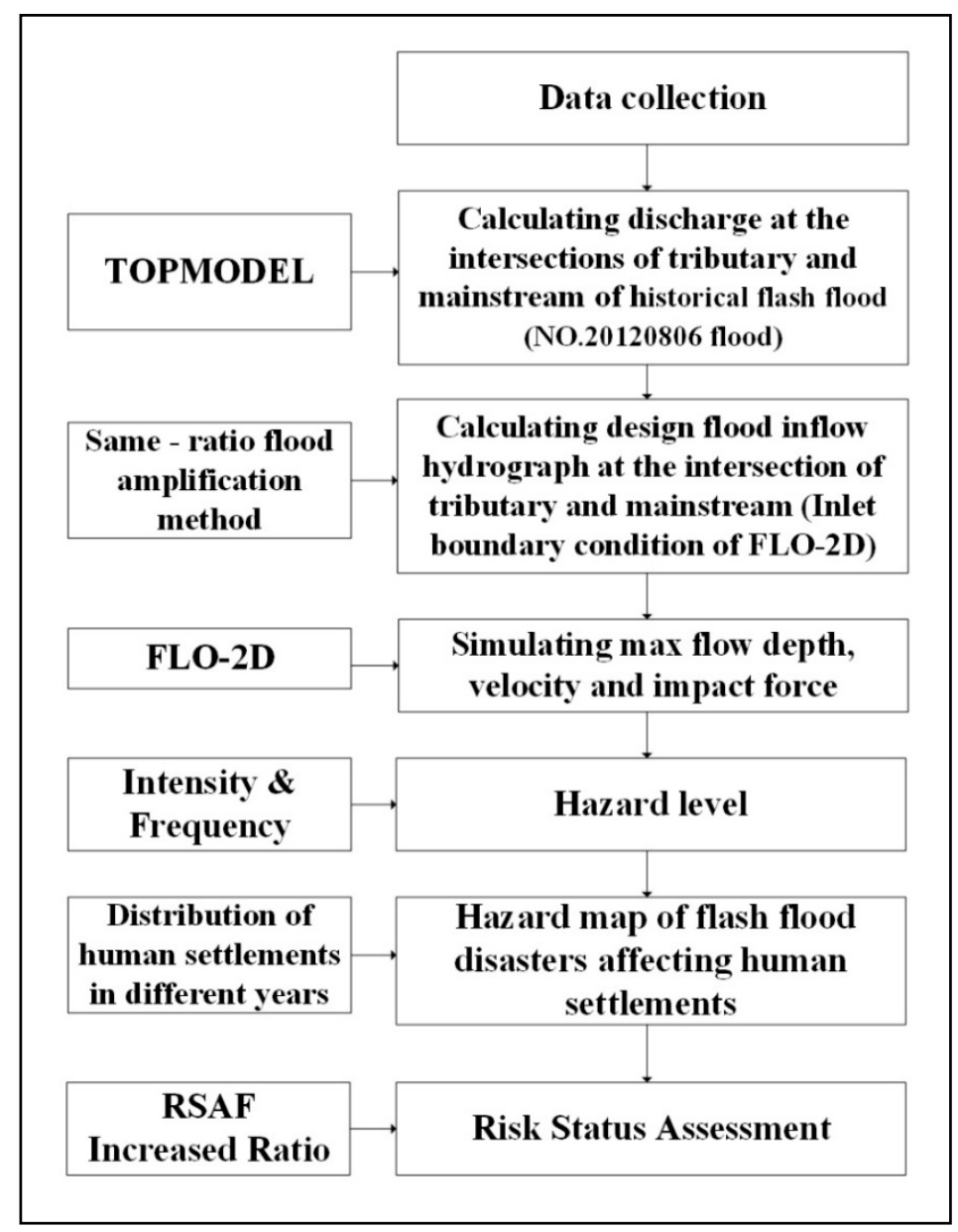

Figure 3. Methodological flowchart.

\subsection{TOPMODEL}

The topography-based hydrological model (TOPMODEL) was originally designed to provide a physically realistic rainfall runoff model, with simple parameters that can predict different types of hydrological responses [17]. Considering the idea proposed by Kirkby [18], the distributed nature of catchment responses in the original model could be indexed based on an analysis of topography. Through preliminary research in Guanshan River Basin, TOPMODEL appeared to be suitable for flood simulation in mountainous areas [12]. TOPMODEL is characterized by a simple design, clear concept, and simplified parameters, providing a model between distributed and centralized hydrological models. The core of TOPMODEL is the topographic index, which is used to reflect the distribution law of inner diameter flow in the basin [19].

The discharge distribution at each grid in the study area was obtained using TOPMODEL simulation. Using TOPMODEL to simulate the No. 20120806 flood, the discharge distribution at the intersection of tributary and main stream was determined, which was used to obtain the inflow hydrograph of a designed flood at the intersection of a tributary and main stream required for FLO-2D simulation.

\subsection{FLO-2D Model}

The FLO-2D model is a product of FLO-2D Software Inc. (FLO-2D Software, Inc., Nutrioso, AZ, USA). It is a finite volume conservation flood routing model that includes the continuity equation and the momentum equation, and is a valuable tool for delineating flood hazards. In FLO-2D, channel flow is one-dimensional, with the channel geometry represented by either natural, rectangular, or 
trapezoidal cross sections. Overland flow is modeled two-dimensionally as either sheet flow or flow in multiple channels [20].

The FLO-2D model is often used to simulate and analyze disasters, such as mudslides and landslides caused by flash floods. Hubl et al. [21] used the FLO-2D model to simulate two typical viscous debris flows and showed that the results simulated by the FLO-2D model were good enough, which proved that the FLO-2D model can be applied to simulate debris flows. Boniello et al. [22] proved that FLO-2D is a useful instrument for simulating debris flow. It charts the possible inundated areas, which is useful for local authorities to complete territorial planning to define the hazardous portions of the territory.

In this study, the inflow hydrograph and DEM were used as the inlet boundary condition for FLO-2D. Since the main stream of the Guanshan River was simulated, the discharge distribution at the intersection of a tributary and the main stream was obtained using TOPMODEL simulation. After completing the flood estimation, the inflow hydrographs of designed flood at the intersection of a tributary and the mainstream were input into FLO-2D. Then, the evaluation indexes of mountain flood disasters, such as maximum flow depth, velocity, and impact force, were simulated based on FLO-2D.

\subsection{Risk Assessment Method for Flash Flood Disasters}

Various methods are available for assessing the risk of flash flood disasters, such as publishing risk index or classifying hazard zones. Zonensein et al. [23] introduced the flood risk index (FRI), which provides the probability of occurrence of an event and the impacts of a flood, demonstrating that the methodology is a valuable planning tool for decision makers. Nasiri et al. [24] introduced a flood vulnerability index (FVI) as a tool for flood risk management that represents areas that are most vulnerable to flooding and require urgent attention. Hazard degree can be evaluated using characteristic values, such as water depth, velocity, and so on. Vojtek and Vojteková [11] used water depth and velocity to confirm hazard degree, and found that the simulation results were consistent with the actual disaster situation, indicating that the method is reliable for confirming the hazard degree. Zhang et al. [25] considered that the water depth multiplied by the velocity is a better technique to develop risk zone maps. In this study, a method of classifying hazard zones was used to assess the risk of flash flood disasters.

Flood risk is determined by frequency and intensity [26]. Flood intensity is defined by the flow depth and velocity. Flood frequency is inversely related to flood magnitude. Large flood events occur less frequently. Flood hazard level is then defined as a discrete combined function of the event intensity and frequency (return period) [27]. In this study, the maximum water depth and maximum flow velocity of each grid were simulated by FLO-2D, so the flood intensity is reported as the maximum depth $h$ and the maximum discharge per unit width $q$, which is the product of maximum depth $h$ and maximum velocity $v$ [28]. According to the "Technical Requirements for Analysis and Evaluation of Mountain Hazards" proposed by the National Flash flood Disaster Prevention Project Team of China, the hazard zone level can be determined by the 5-, 20-, and 100-year return periods to confirm hazard degree [29]. We referred to the measurement standard with those return periods to define the flood frequency.

For regional economic development, the distribution of human activities is most important, including the distribution of population, houses, and fields. To evaluate the relationship between regional development and flash flood disasters, we selected the distribution of population and houses in the study areas in 2003, 2013, and 2018, and analyzed the distribution of hazard zones in the Guanshan River Basin. To obtain accurate distributions of houses and fields, the locations of the study area were determined from remote sensing images, using Google Earth (Google, Mountain view, CA, USA) to confirm the hazard degree, so that the houses and fields could be framed. 
To further evaluate the risk status of flash flood disasters in the Guanshan River Basin, the RSAF of flash flood disasters was developed, as shown in Equation (1):

$$
R S A F=\frac{\alpha \times R+\beta \times H+\gamma \times E}{T A}
$$

where $R, H$, and $E$ represent areas with risk, high risk, and extreme risk, respectively; $\alpha, \beta$, and $\gamma$ are the weights of $R, H$, and $E$, respectively; and TA represents the total area of the simulated basin. According to the regulations on the prevention and control of geological hazards in China [30], the level of flash flood disasters is evaluated based on the degree of economic loss, through which it can be defined as extremely large-scale, large-scale, medium-scale, and small-scale disaster when the direct economic loss is greater than 10 million RMB (about $\$ 1.40$ million), 5 million RMB (about $\$ 0.70$ million) to 10 million RMB (about $\$ 1.40$ million), 1 million RMB (about $\$ 0.14$ million) to 5 million RMB (about $\$ 0.70$ million), and less than 1 million RMB (about $\$ 0.14$ million), respectively. Therefore, the amounts of economic loss, which are 1,5, and 10 million yuan, can be taken as the threshold values. To express the Equation (1) more concisely, the percentages of economic loss were used as the weight; that is, $\alpha, \beta$, and $\gamma$ are taken as $1 / 16,5 / 16$, and $10 / 16$, respectively.

To compare the risk status of flash flood disasters more clearly, based on $R S A F$, the increased ratios of different hazard level in different years were calculated, as shown in Equation (2):

$$
\text { Increased Ratio }=\frac{a-b}{b} \times 100 \%
$$

where $a$ represents the $R S A F$ of the later period and $b$ represents the $R S A F$ of the early period. For example, if the RSAF for different hazard levels in 2003 and 2013 are compared, $a$ represents $R S A F$ in 2013 and $b$ represents $R S A F$ in 2003.

\section{Results}

\subsection{Designed Flood Estimation}

To build the model, the annual peak discharge data were first obtained from the measured discharge data. The historical survey period was from 1935 to 2018, including two catastrophic floods and 22 years of measured discharge data, which were arranged from high to low. The unified approach was used to calculate the frequency, and the empirical frequency of the annual peak discharge of the Gushan station was calculated. The Pearson III distribution (P-III) curve was used for fitting [31]. According to the estimated fitting, the result was optimized by calculating the empirical data and the least squares longitudinal deviation of the P-III curve obtained by the fitting, to obtain the frequency curve of peak discharge of Gushan station, as shown in Figure 4a. The mean of the discharge (Ex) was $241.08 \mathrm{~m}^{3} / \mathrm{s}$, the coefficient of variation $(\mathrm{Cv})$ was 1.85 , and the coefficient of skewness (Cs) was 4.591 .

Through the curve, the peak discharges of flood with designed frequencies of $1 \%, 2 \%, 5 \%, 10 \%$, and $20 \%$ were obtained, which were divided by the peak discharge of the flood on 5 August 2012, which was taken as a typical flood, allowing the magnification factor to be obtained, as shown in Table 2. 


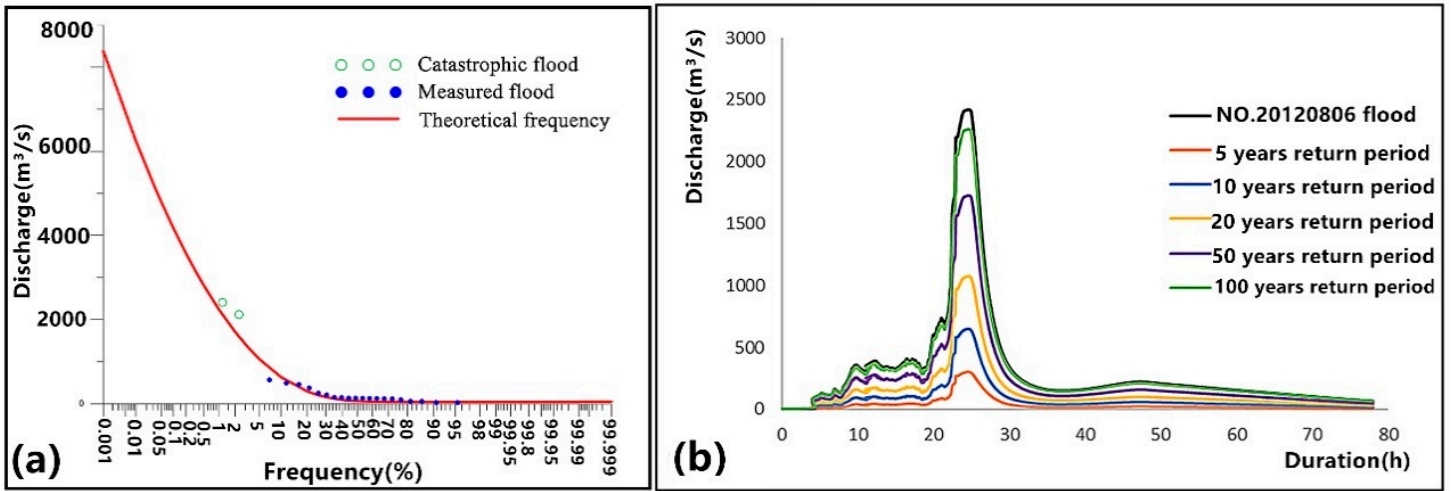

Figure 4. Flood estimation of Guanshan River: (a) frequency curve of peak discharge of Gushan Station in the Guanshan River Basin; (b) discharge hydrograph of a typical flood and the designed flood.

Table 2. Peak discharge of designed floods and magnification ratio for Gushan Station.

\begin{tabular}{cccc}
\hline $\begin{array}{c}\text { Peak Discharge of } \\
\text { Typical Flood }\left(\mathbf{m}^{3} / \mathbf{s}\right)\end{array}$ & $\begin{array}{c}\text { Return Period of } \\
\text { Designed Flood }\end{array}$ & $\begin{array}{c}\text { Peak Discharge of } \\
\text { Designed Flood }\left(\mathbf{m}^{\mathbf{3}} \mathbf{s}\right)\end{array}$ & Magnification Factor \\
\hline & 5-year & 295.56 & 0.123 \\
& 10-year & 633.92 & 0.263 \\
2410 (5 August 2012) & 20-year & 1061.40 & 0.440 \\
& 50-year & 1712.70 & 0.711 \\
& 100-year & 2248.61 & 0.933 \\
\hline
\end{tabular}

Because the flood data of the Guanshan River Basin are relatively complete and the flood peak and volume relationship is strong, the rates of peak discharge of the designed floods with different designed frequencies were calculated and used to amplify the discharge hydrograph of the designed floods, as shown in Figure $4 b$.

In this study, the data used to extract the topographic index were obtained from the $10 \mathrm{~m}$ DEM mentioned above. The main steps for extracting the topographic index through ArcGIS (Environmental Systems Research Institute, Redlands, CA, USA) were as follows: filling DEM, extracting flow direction, calculating accumulation, dividing watershed, and extracting slope. The frequency distribution of the topographic index in Guanshan River Basin is shown in Figure 5.

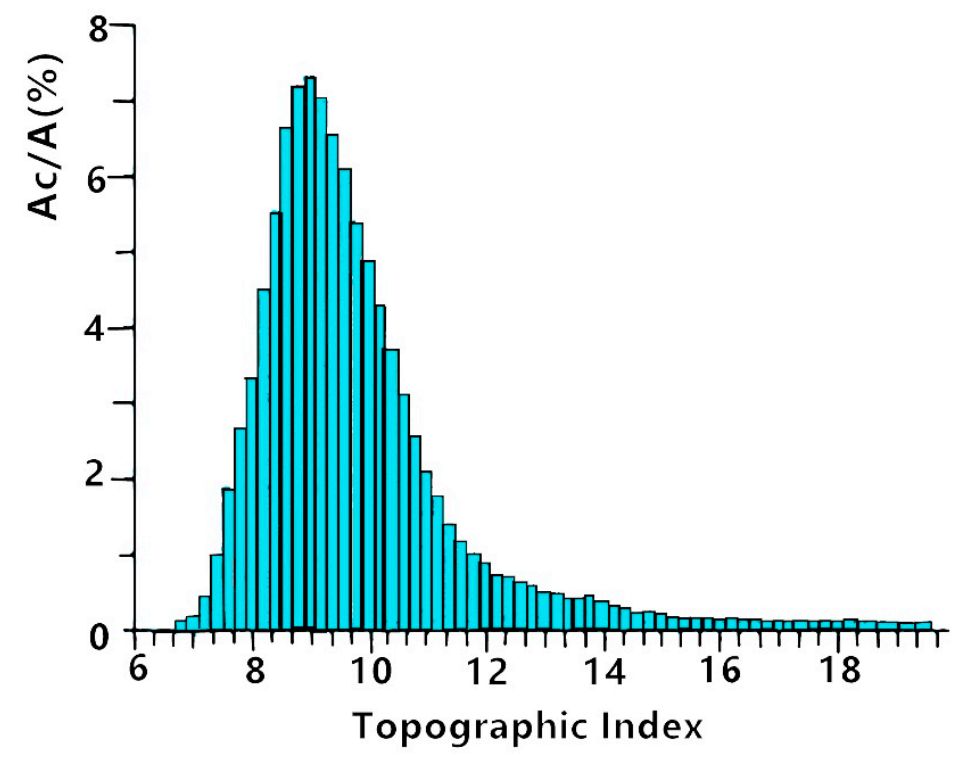

Figure 5. Frequency distribution of the topographic index. 
To use TOPMODEL for hydrological simulation, the accuracy was evaluated according to "Standard for hydrological information and hydrological forecasting" GB/T 22482-2008 [32]. The assessment indicators selected in this study included the Nash-Sutcliffe model efficiency coefficient (NSE), error of runoff volume, peak discharge error, and difference in time between simulated and observed peak occurrence. The genetic algorithm was used to optimize parameters in the TOPMODEL calibration [33]. The calibration period was chosen from 2009 to 2013, while the validation period was 2014 to 2015. The results of the TOPMODEL calibration and validation are shown in Table 3.

Table 3. Results of topography-based hydrological model (TOPMODEL) calibration and validation.

\begin{tabular}{|c|c|c|c|c|c|}
\hline Period & $\begin{array}{l}\text { Flood Number } \\
\text { (DDMMYYYY) }\end{array}$ & $\begin{array}{c}\text { Error of } \\
\text { Runoff } \\
\text { Volume (\%) }\end{array}$ & $\begin{array}{c}\text { Peak } \\
\text { Discharge } \\
\text { Error (\%) }\end{array}$ & $\begin{array}{c}\text { Difference in Time } \\
\text { between Simulated and } \\
\text { Observed Peak } \\
\text { Occurrence (Hour) }\end{array}$ & NSE \\
\hline \multirow{12}{*}{ Calibration } & 19042009 & 17.42 & 20.00 & 0 & 0.84 \\
\hline & 27052009 & 45.90 & 33.66 & 1 & 0.30 \\
\hline & 08062010 & 44.77 & 41.35 & 0 & 0.70 \\
\hline & 19072010 & 25.32 & 26.18 & 0 & 0.77 \\
\hline & 02082010 & 1.98 & 2.39 & 1 & 0.88 \\
\hline & 25082010 & 30.15 & 39.73 & 0 & 0.71 \\
\hline & 06092010 & 36.12 & 15.22 & 0 & 0.79 \\
\hline & 19092010 & 26.80 & 35.26 & 0 & 0.83 \\
\hline & 10072012 & 32.89 & 49.98 & 0 & 0.66 \\
\hline & 06082012 & 18.91 & 13.97 & 0 & 0.93 \\
\hline & 21082012 & 1.64 & 26.18 & 0 & 0.78 \\
\hline & 11092012 & 15.06 & 21.90 & 0 & 0.50 \\
\hline Average & & 24.75 & 27.15 & 0.17 & 0.72 \\
\hline \multirow{6}{*}{ Validation } & 18092014 & 12.14 & 4.66 & 0 & 0.98 \\
\hline & 28092014 & 15.79 & 21.80 & 1 & 0.79 \\
\hline & 202102014 & 8.85 & 19.53 & 0 & 0.92 \\
\hline & 06042015 & 28.31 & 1.01 & 0 & 0.53 \\
\hline & 09082015 & 4.58 & 13.04 & 0 & 0.78 \\
\hline & 19082015 & 19.00 & 16.13 & 1 & 0.94 \\
\hline Average & & 14.78 & 12.70 & 0.33 & 0.82 \\
\hline
\end{tabular}

The overall NSE of the validation was 0.84 , and the NSE of the validation period was 0.80 . According to the results of the flood simulation and forecast in specific sessions, the results of calibration and validation were sufficient. The model is suitable for risk assessment.

In Table $4, T_{0}\left(\mathrm{~m}^{2} \cdot \mathrm{h}^{-1}\right)$ represents the lateral downslope transmissivity when the soil is just saturated; $t_{d}\left(\mathrm{~h} \cdot \mathrm{m}^{-1}\right)$ represents a time delay constant that introduces longer residence times to cater for deep water table levels; $S_{\text {rmax }}(\mathrm{m})$ represents the maximum root zone storage; $Q_{b}^{1}\left(\mathrm{~m} \cdot \mathrm{h}^{-1}\right)$ represents the initial interflow in the basin; $f_{0}\left(\mathrm{~mm} \cdot \mathrm{h}^{-1}\right)$ represents the initial infiltration capacity; $f_{c}\left(\mathrm{~mm} \cdot \mathrm{h}^{-1}\right)$ represents the final infiltration capacity; $k$ represents the decay constant; $n$ represents Manning's roughness coefficient [34].

Table 4. TOPMODEL parameters table.

\begin{tabular}{ccccccccc}
\hline$T_{\mathbf{0}}$ & $\boldsymbol{t}_{\boldsymbol{d}}$ & $S_{\text {rmax }}$ & $Q_{b}^{1}$ & $K_{s}$ & $f_{0}$ & $f_{c}$ & $k$ & $n$ \\
\hline 0.597 & 3.816 & 0.680 & 1.387 & 0.437 & 15.885 & 5.832 & 3.478 & 3.766 \\
\hline
\end{tabular}

\subsection{Flash Flood Disasters Simulation}

To establish the FLO-2D model, the DEM was imported into the FLO-2D numerical simulation software. The grid resolution was $10 \times 10 \mathrm{~m}$. The watershed boundary of the imported shape format was recognized as the calculated boundary. The elevation points of each grid were interpolated by at least two adjacent elevations of imported DEM [20]. 
According to the natural river roughness table [35], for small rivers in a mountainous area, when there are pebbles and large orbs at the bottom of the river, the roughness ranges from 0.040 to 0.070 . For the Courant number of a floodplain and the numerical stability parameter of surface detention, according to the characteristics of the stream flood, they range from 0.3 to 0.7 and 0.0012 to 0.03 , respectively [36]. Finally, by comparing the simulated results with the actual results, the roughness was selected as 0.06 . The Courant number of the floodplain was 0.6 , and the numerical stability parameter of surface detention was 0.03 .

The watershed model based on FLO-2D was used to simulate the measured flood on 5 August 2012, and the disaster accident point was simulated, including the maximum flow depth, maximum velocity, and maximum impact force, as shown in Table 5.

Table 5. Comparison of disasters simulation results and actual situation of No. 20120806 flood.

\begin{tabular}{cccccc}
\hline $\begin{array}{c}\text { Accident } \\
\text { Positions }\end{array}$ & $\begin{array}{c}\text { Simulated } \\
\text { Max Velocity } \\
(\mathbf{m} / \mathbf{s})\end{array}$ & $\begin{array}{c}\text { Simulated } \\
\text { Max Impact } \\
\text { Force (MN/m) }\end{array}$ & $\begin{array}{c}\text { Simulated } \\
\text { Max Flow } \\
\text { Depth (m) }\end{array}$ & $\begin{array}{c}\text { Measured Max } \\
\text { Water Depth } \\
(\mathbf{m})\end{array}$ & $\begin{array}{c}\text { Percent Error } \\
(\%)\end{array}$ \\
\hline 1 & 5.42 & 7.00 & 4.98 & 4.94 & 0.96 \\
2 & 5.36 & 6.33 & 5.06 & 5.09 & 0.59 \\
3 & 0.82 & 0.12 & 3.52 & 3.55 & 1.02 \\
4 & 4.61 & 3.25 & 4.41 & 4.35 & 1.29 \\
5 & 3.44 & 1.78 & 4.00 & 4.06 & 1.50 \\
6 & 6.19 & 8.65 & 5.46 & 5.38 & 1.48 \\
7 & 1.20 & 0.09 & 1.30 & 1.27 & 2.53 \\
\hline
\end{tabular}

From the comparison between the simulation results and measured max flow depth in Table 5, the simulation results were found to be basically consistent with the actual results. The simulated max flow depths were matched with actual accident situations, such as Positions 1, 2, 3, 4, and 6. We found that the percent errors of the simulated and measured max flow depth were not greater than $3 \%$. As shown in Table 1, in the actual investigation in Position 3, the bridge was inundated. This is consistent with the height of the bridge from the riverbed. In the actual investigation at Position 2, the department of highway management was destroyed, and the simulated water velocity and impact force values were larger than at other points, which is consistent with the disaster situation. Therefore, after the parameter calibration, the watershed model based on FLO-2D was found to be accurate and reliable and could be used to simulate flash flood disasters for Guanshan River.

Based on the TOPMODEL and FLO-2D model, the designed flood disasters were calculated, which are shown in Figure 6. 


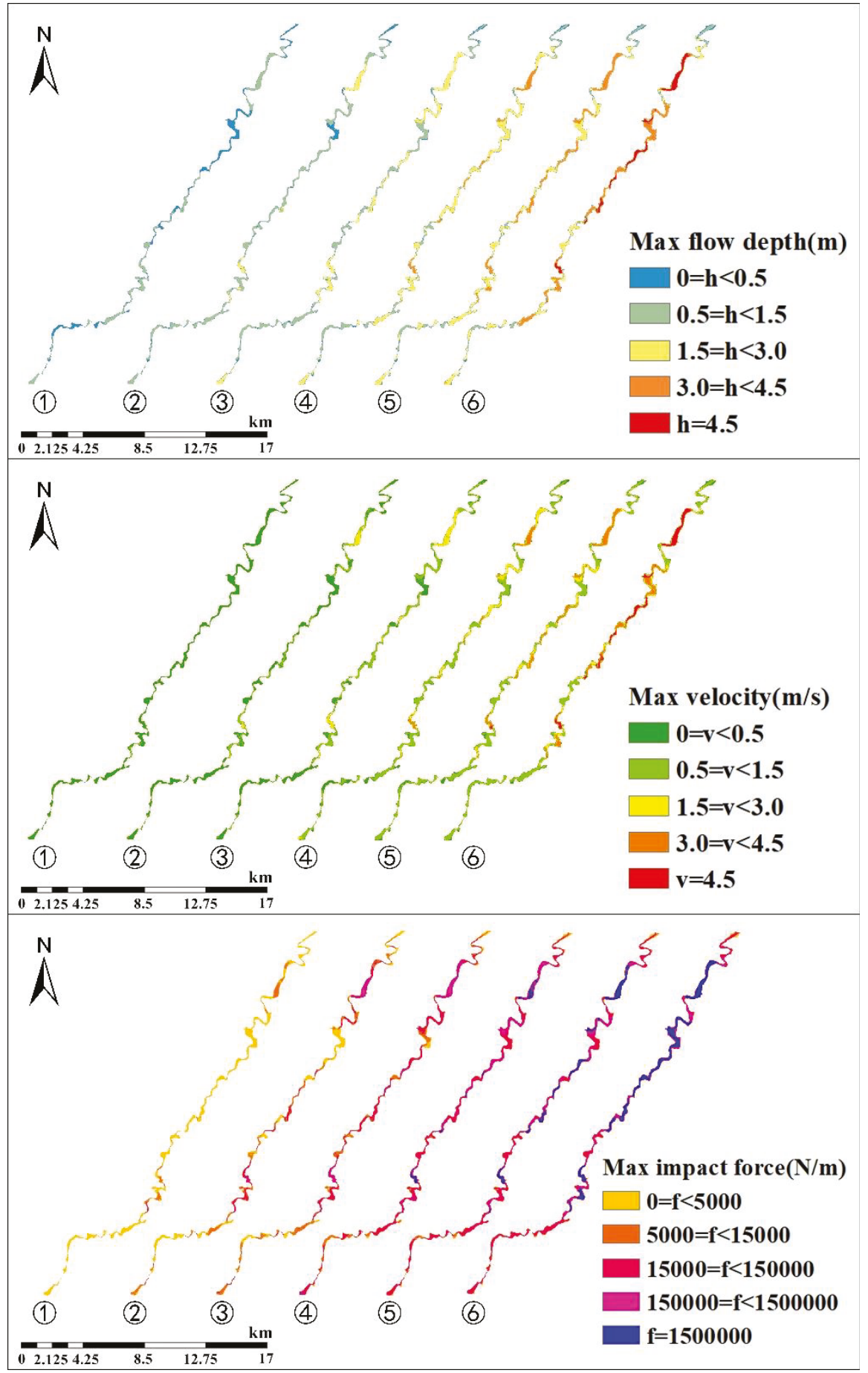

Figure 6. Simulation of No. 20120806 flood and designed floods (1)-(6) indicate 5-, 10-, 20-, 50-, and 100-year return periods and No. 20120806 flood, respectively).

\subsection{Hazard Map of Flash Flood Disasters}

According to the Technical Requirements for Analysis and Evaluation of Mountain Flood Disasters, China [29], considering the actual local situation, the maximum depth $h$ and maximum discharge per unit width $q$ were used to define the flood intensity, as shown in Table 6. 
Table 6. Definition of flood intensity.

\begin{tabular}{ccccc}
\hline $\begin{array}{c}\text { Flood } \\
\text { Level }\end{array}$ & $\begin{array}{c}\text { Flood } \\
\text { Intensity }\end{array}$ & $\begin{array}{c}\text { Maximum Depth } \\
\boldsymbol{h}(\mathbf{m})\end{array}$ & Relationship & $\begin{array}{c}\text { Maximum Discharge per } \\
\text { Unit Width } \boldsymbol{q}\left(\mathbf{m}^{2} / \mathbf{s}\right)\end{array}$ \\
\hline 1 & Low & $0<h<1 \mathrm{~m}$ & And & $0<q<2 \mathrm{~m}^{2} / \mathrm{s}$ \\
2 & Medium & $1 \leq h<2.5 \mathrm{~m}$ & Or & $2 \leq q<10 \mathrm{~m}^{2} / \mathrm{s}$ \\
3 & High & $h \geq 2.5 \mathrm{~m}$ & Or & $q \geq 10 \mathrm{~m}^{2} / \mathrm{s}$ \\
\hline
\end{tabular}

According to the definition of flood intensity, the flood intensities of No. 20120806 and the designed flood with the five different frequencies were calculated, as shown in Figure 7.

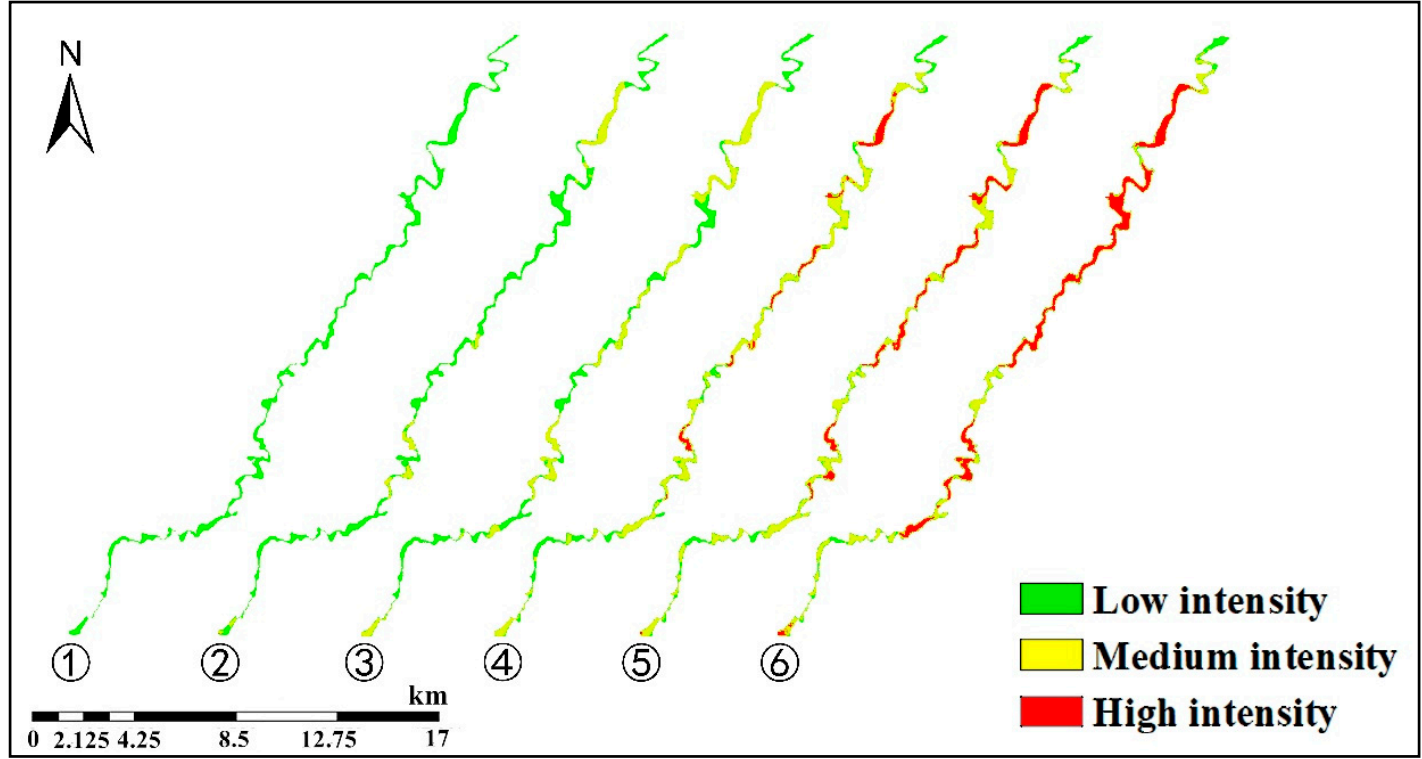

Figure 7. Simulated flood intensity distribution of No. 20120806 and designed floods (1)-(6) indicate 5-, 10-, 20-, 50-, and 100-year return periods and No. 20120806 flood, respectively).

The statistics of flood intensity of No. 20120806 and the designed floods with five different frequencies, that is, the percentage of each flood intensity level to the total intensity distribution, are shown in Table 7.

Table 7. Distribution of flood intensity.

\begin{tabular}{ccccc}
\hline Flood Type & $\begin{array}{c}\text { Percentage of Low } \\
\text { Intensity (\%) }\end{array}$ & $\begin{array}{c}\text { Percentage of } \\
\text { Medium Intensity (\%) }\end{array}$ & $\begin{array}{c}\text { Percentage of } \\
\text { High Intensity (\%) }\end{array}$ & $\begin{array}{c}\text { Total Area } \\
\left(\mathbf{k m}^{\mathbf{2}} \mathbf{)}\right.\end{array}$ \\
\hline No. 20120806 flood & 20.49 & 31.09 & 48.42 & 7.17 \\
5-year return period & 99.68 & 0.32 & 0.00 & 6.58 \\
10- year return period & 79.94 & 20.06 & 0.00 & 6.22 \\
20-year return period & 57.86 & 42.14 & 0.00 & 5.67 \\
50-year return period & 33.28 & 51.56 & 15.16 & 5.17 \\
100-year return period & 26.06 & 45.64 & 28.30 & 4.51 \\
\hline
\end{tabular}

Table 7 shows that the flood with a lower designed frequency is more intense, and the lower designed frequency of the flood may cause a larger proportion of high intensity level. To confirm the flood frequency, we referred to the measurement standard with 5-, 20-, and 100-year return periods. Based on the above-mentioned hazard level criteria, considering the flood intensity of the designed flood frequencies, the hazard distribution of the Guanshan River was calculated. The hazard level distribution was obtained from the calculation of the hazard distribution of the Guanshan River, and then the area of each hazard level was analyzed. The results are shown in Table 8. The hazard distribution map of Guanshan River was obtained, as shown in Figure 8. 
Table 8. Hazard distribution of Guanshan River.

\begin{tabular}{cccccc}
\hline Hazard Level & $\begin{array}{c}\text { Flood Return } \\
\text { Period (Years) }\end{array}$ & Frequency & $\begin{array}{c}\text { Area } \\
\mathbf{( k m}^{\mathbf{2}} \mathbf{)}\end{array}$ & $\begin{array}{c}\text { Percentage of the } \\
\text { Total Area of } \\
\text { Hazard Zones (\%) }\end{array}$ & $\begin{array}{c}\text { Percentage of the } \\
\text { Area of the } \\
\text { Simulated Basin (\%) }\end{array}$ \\
\hline $\begin{array}{c}\text { Risk } \\
\text { High risk }\end{array}$ & 100 & Low & 1.72 & 25.99 & 10.52 \\
Extreme risk & 50 & Medium & 3.02 & 45.74 & 18.47 \\
\hline $\begin{array}{c}\text { Total area of } \\
\text { simulated basin }\end{array}$ & \multicolumn{7}{|c}{16.35} \\
\hline
\end{tabular}

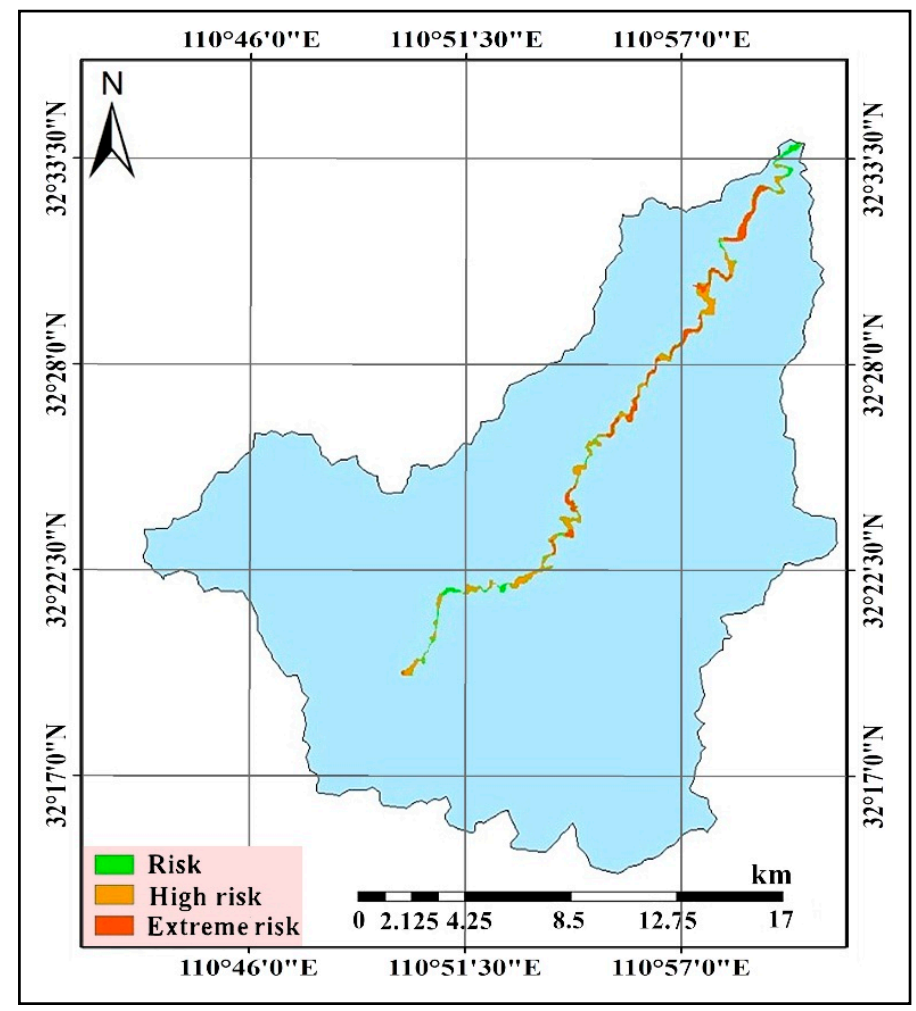

Figure 8. Distribution of flash flood disasters in Guanshan River.

Figure 8 shows that the hazard distribution of Guanshan River is dense along the river. The high risk zones account for the highest proportion, which is $45.74 \%$, mainly distributed in the middle and upper reaches; followed by the extreme risk zones, accounting for $28.28 \%$, mainly distributed in the middle and lower reaches; the risk zones accounting for $25.99 \%$, mainly distributed in the upstream. This shows that the risks are greater if people live in the middle and lower reaches. Therefore, we then further analyzed the hazard distribution in human settlements.

\subsection{Risk Status Assessment for Flash Flood Disaster}

In the past few decades, China's economy has developed quickly. According to census data, the total population in the Guanshan Basin has fluctuated in the past few years, as shown in Figure 9. The population along the Guanshan River first increased and then declined slightly. Figure 10 shows that houses along the Guanshan River followed the same rule. In the Guanshan River Basin, over time and with economic development, more people who originally lived in the mountains have migrated near to the river to seek better living conditions. 


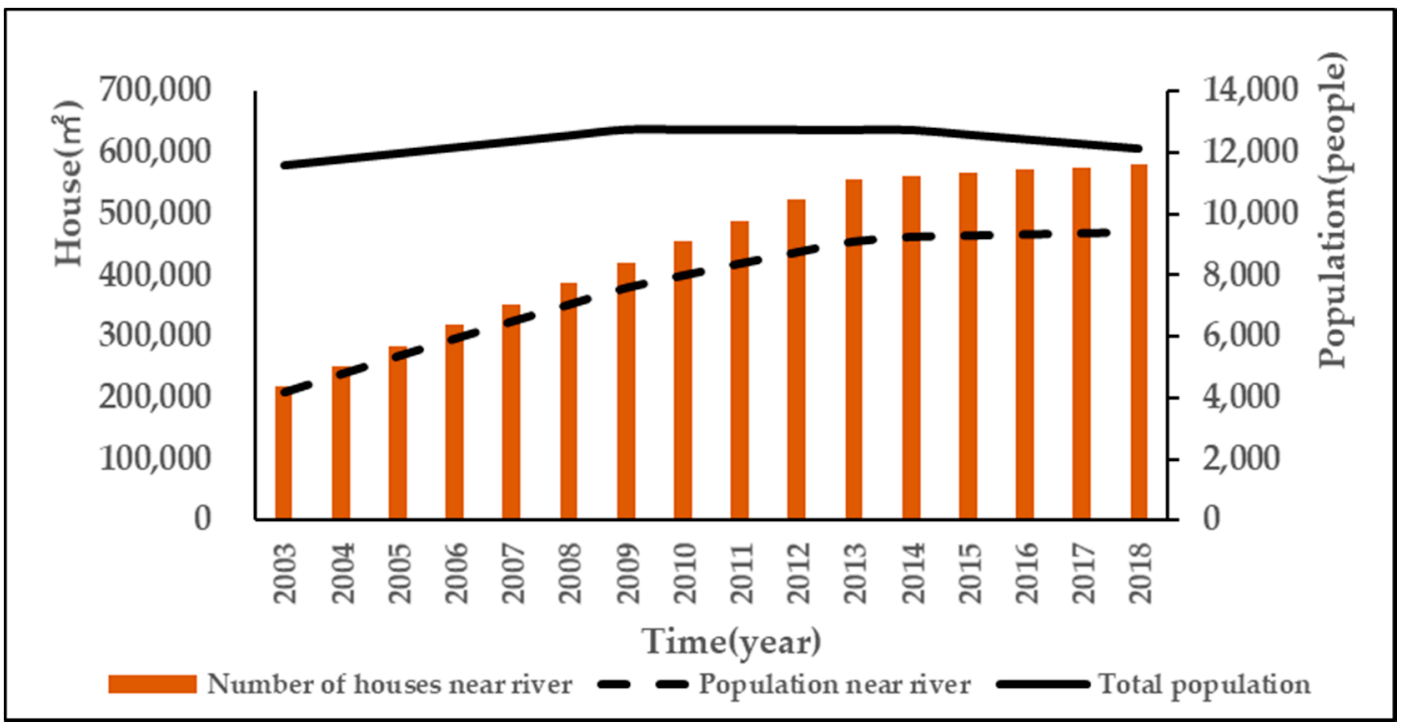

Figure 9. Distribution of flood disasters in No. 20120806 flood and hazard map of human settlements.

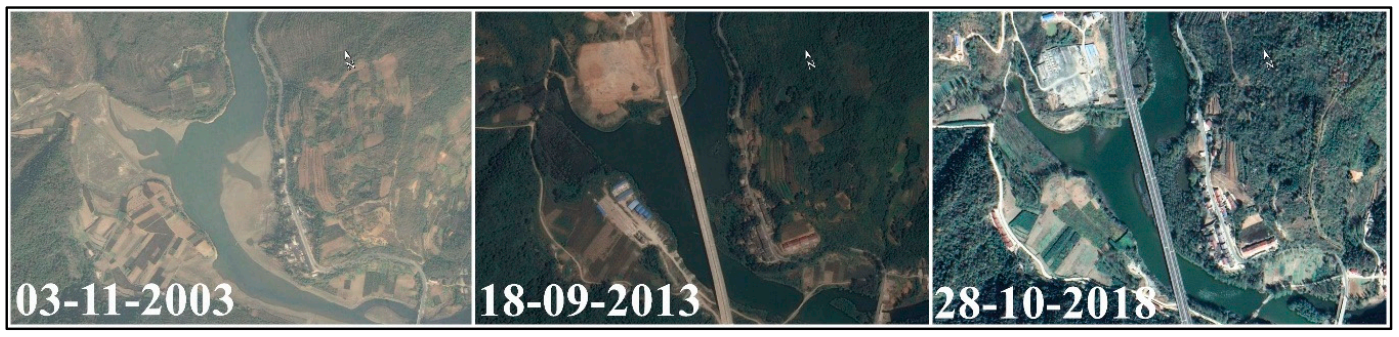

Figure 10. Changes in houses along the Guanshan River in 2003, 2013, and 2018. (Images obtained from SPOT-5 Satellite of Google Earth).

Due to the close relationship between the flash flood hazard zones and human settlements, we compared the human settlements with flash flood hazard zones on spatial and temporal scales. Based on the census data, by selecting satellite remote sensing images with better quality for inversion, we determined the population and house distribution in the Guanshan River Basin in 2003, 2013, and 2018, and analyzed the distribution of hazard zones in the Guanshan River Basin. The distribution of houses and fields were obtained by determining the location of the study area on remote sensing images through Google Earth.

According to Equation (1), the RSAF of flash flood disasters in 2003, 2013, and 2018 were calculated, as shown in Table 9. To more clearly compare the risk status of flash flood disasters in 2003, 2013, and 2018, according to the calculated RSAF, the increased ratios of different hazard levels in 2013 and 2003, 2018 and 2003, and 2018 and 2013 were calculated, as shown in Table 9.

Table 9. Hazard area of human settlements in Guanshan River.

\begin{tabular}{|c|c|c|c|c|c|c|c|c|c|}
\hline \multirow[b]{2}{*}{ Hazard Level } & \multicolumn{3}{|c|}{ Hazard Area $\left(\mathrm{m}^{2}\right)$} & \multicolumn{3}{|c|}{ RSAF } & \multicolumn{3}{|c|}{ Increased Ratio } \\
\hline & 2003 & 2013 & 2018 & 2003 & 2013 & 2018 & $\begin{array}{c}2003 \text { to } \\
2013\end{array}$ & $\begin{array}{c}2003 \text { to } \\
2018\end{array}$ & $\begin{array}{c}2013 \text { to } \\
2018\end{array}$ \\
\hline Risk & 13,416 & 38,210 & 36,133 & 0.05 & 0.15 & 0.14 & $185 \%$ & $169 \%$ & $-5 \%$ \\
\hline High risk & 38,141 & 72,261 & 57,571 & 0.73 & 1.38 & 1.10 & $89 \%$ & $51 \%$ & $-20 \%$ \\
\hline Extreme risk & 9564 & 29,283 & 24,700 & 0.37 & 1.12 & 0.94 & $206 \%$ & $158 \%$ & $-16 \%$ \\
\hline All & 61,121 & 139,754 & 118,404 & 1.15 & 2.65 & 2.18 & & & \\
\hline
\end{tabular}

From Figure 11 and Table 9, over time, the three levels of hazard areas basically showed the trend of rising first and then declining slightly. This trend is basically consistent with the trend in population 
change along the river. The high-risk zones were always larger than those of risk and extreme risk zones for the same year. That means, for the Guanshan River Basin, the risk of flash flood disasters in human settlements first increased and then declined slightly.

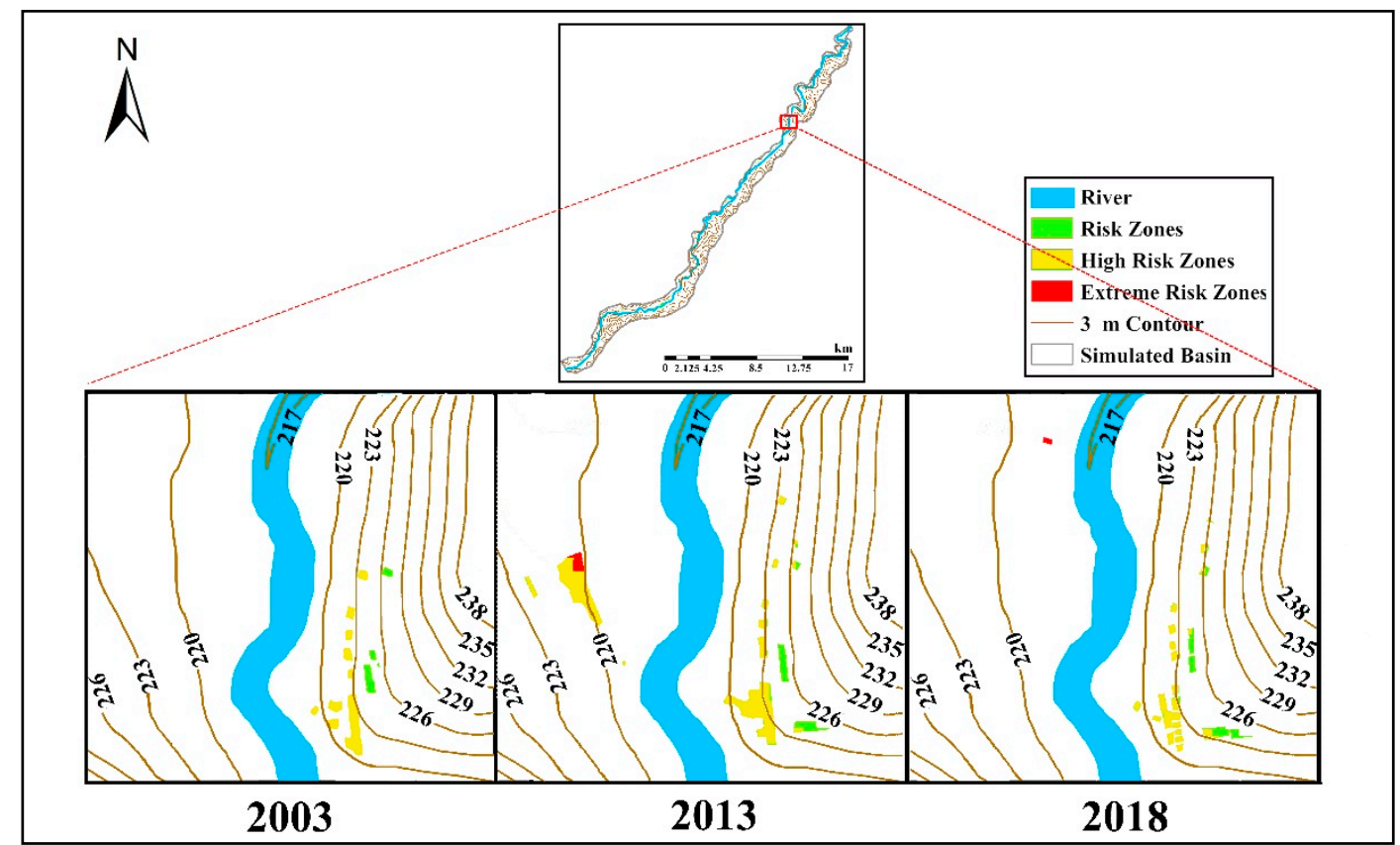

Figure 11. Distribution of flash flood disasters in the human settlements of the Guanshan River in recent years. The blue river is just a sketch, as its bed is often bare.

On the spatial scale, the population and houses along the river in the downstream area increased more than in the upper and middle reaches. Therefore, the distribution of high risk and extreme risk zones in flash flood disasters in downstream areas was always greater than in the upper and middle areas. This may be because, in the downstream area, the water resources are more abundant, while the terrain is flatter and transportation is more convenient, so downstream areas are more livable and residents may migrate there more.

According to the calculated $R S A F$, regardless of year, high risk zones have the greatest impact, followed by extreme risk zones, and the smallest are risk zones. Although the extreme risk areas are not large, the risk of flash flood disasters is the highest, so they have a greater impact on the risk status of flash flood disasters. This shows that RSAF intuitively reflects the risk status of flash flood disasters in the Guanshan River Basin. The flood hazard map is good at judging the spatial distribution of risk. However, it is just a static evaluation factor and still needs a more comprehensive factor to intuitively and dynamically quantify the flood risk. $R S A F$ is actually a further summary of typical flood hazards maps, taking into account changes in human settlements over time, which can be used for a comprehensive assessment during regional long-term planning.

In regard to the increased ratios, compared with 2003, in 2013, the extreme risk zones had the largest increased ratio, and in 2018, the risk zones had the largest increased ratio. Compared with 2013 , in 2018 , the reduction ratio of high risk zones was the largest, followed by the extreme high zones. Since 2003, with the development of the regional economy, more residents moved to the river valley, mainly concentrated in risk and extreme risk zones, which increased the overall risk of flash flood disasters. From 2013 to 2018, the number of residents living in high risk and extreme risk zones decreased. Most likely due to the huge losses caused by the flash flood disasters on 5 August 2012, local residents moved away from the high risk and extreme risk zones. Meanwhile, the reduction in the risk zones was not obvious. 
Due to economic development, people often move to economically better towns along the river to seek better living conditions. However, for the choice of house relocation, the high risk and extreme risk zones of flash flood disasters should be avoided as much as possible, to ensure greater security.

\section{Discussion}

In this study, the FLO-2D model was used for flood simulation. It is sometimes calibrated and verified by comparing the experimental results with the physical model [37]. In most cases, calibration and verification data are rare [38]. To perform calibration and verification, scholars conduct mountain surveys in the study area [39], or record actual measurements and compare the simulated results with the actual situation [40]. With regard to the calibration or validation of the model result, to produce reliable results, we used as much accurate and high-quality input data as possible, conducted field surveys in the early stages, and obtained data of the measured max flow depth to determine actual conditions of flash flood disasters and to enable comparison with the FLO-2D simulated results.

As for flash flood disaster risk assessment, the maximum water depth and maximum flow velocity of each grid were used to divide hazard degrees in this study. This method has also been applied in other places (e.g., Vojtek and Vojteková [11] and Kourgialas and Karatzas [41]). There are several approaches for defining water depth-velocity hazard categories. Hazard categories were modified according to Loat [28] in our study. In addition, the actual situation of flash flood disasters in China were considered, and the hazard levels were divided into three levels, according to 5-, 20-, and 100-year return periods [29], to better describe the flash flood disaster situation in the study area. To further assess the risk status of flash flood disasters in different years, a method called RSAF was developed to intuitively reflect the risk status of flash flood disasters in the Guanshan River Basin. In this study, according to the regulations on the prevention and control of geological hazards in China [30], the amounts of economic loss were taken as the threshold values, so that the actual situation in China could be considered when selecting RSAF parameters.

To consider the flood damage, the indirect flood damage was evaluated by analyzing the flash flood disasters in human settlements. Direct flood damage to buildings [42] was further considered in this study, to consider floodwater hydrodynamics in the vulnerability assessment of buildings located in flood prone areas [43].

\section{Conclusions}

We selected the Guanshan River Basin as the research area, simulated the inflow hydrograph using TOPMODEL, and built a watershed model based on FLO-2D to simulate the No. 20120806 flood. Compared with the actual disaster situation, the parameters were calibrated, and the FLO-2D model applicable to the Guanshan River area was established. The floods designed with different frequencies were estimated, and the disaster assessment parameters, such as maximum flow depth, maximum velocity, and maximum impact force, were obtained, and the designed flood intensity was analyzed. According to the classification of hazard levels, the hazard distribution map of the Guanshan River was drawn. Compared with the population distribution of Guanshan River in the past 15 years, the map shows that the probability of loss and casualties caused by flash flood disasters increased first and then declined slightly. The main findings of this study are as follows:

Simulating the hazard distribution of flash flood disasters in Guanshan River, No. 20120806 flood was selected as a typical flood and the designed floods were chosen with 5-, 10-, 20-, 50-, and 100 -year return periods. The inflow hydrographs were simulated by TOPMODEL and the maximum flow depth, maximum velocity, and maximum impact force were simulated by FLO-2D. According to the classification criteria of flash flood disasters along Guanshan River, the hazard distribution map of flash flood disasters for Guanshan River was drawn, which showed that the flood hazards of Guanshan River are densely distributed along the river, especially in the middle and lower reaches. The simulated disaster distribution is basically consistent with the actual disaster situation. Therefore, the hazard distribution map of flash flood disasters of Guanshan River was found to be reasonable. 
(1) Simulating the hazard distribution of flash flood disasters in Guanshan River. No. 20120806 flood was selected as a typical flood and the designed floods were chosen with 5-, 10-, 20-, 50-, and 100 -year return periods. The inflow hydrographs were simulated by TOPMODEL, and the maximum flow depth, maximum velocity, and maximum impact force were simulated by FLO-2D. According to the classification criteria of flash flood disasters along Guanshan River, the hazard distribution map of flash flood disasters for Guanshan River was drawn, which showed that the flood hazards of Guanshan River are densely distributed along the river, especially in the middle and lower reaches. The simulated disaster distribution is basically consistent with the actual disaster situation. Therefore, the hazard distribution map of flash flood disasters of Guanshan River was found to be reasonable.

(2) Developing the risk status assessment factor (RSAF) for flash flood disasters and then calculating the increased ratio, so that the risk status of flash flood disasters in different years could be assessed intuitively. Using the assessment, the risk trend of flash flood hazard in the study area was obtained intuitively during regional economic development. $R S A F$ is a further summary of typical flood hazards maps, considering changes in human settlements over time, which is conducive to the comprehensive evaluation of regional long-term planning. Therefore, during regional economic development planning, $R S A F$ can provide a reference to help people to avoid the risk of flash flood disasters, and thus reduce economic losses. From a methodological perspective, the importance of the study is in the proposed $R S A F$, which can be used for a comprehensive assessment of the risk of flash flood disasters during regional economic planning. Further case studies in other regions should be undertaken to verify the general applicability of the RSAF.

(3) Comparing the population distribution of the Guanshan River Basin in the past 15 years, we found that, in the human settlement, the hazard distribution area has expanded, and the probability of loss and casualty caused by flash flood disasters is increasing, which means that the risk of a flash flood hazard is consistent with the regional development of Guanshan River. According to the RSAF, although the area of extreme risk zones is not large, it has a greater impact on the risk status, due to having the highest risk of flash flood disasters. According to the increased ratio, since 2003, with the development of the regional economy, more residents moved to the risk and extreme risk zones, which increased the overall risk of flash flood disasters. From 2013 to 2018, most likely due to the huge losses caused by the flash flood disaster on 5 August, 2012, local residents moved away from the high risk and extreme risk zones. The findings provide practical guidance for flood control and disaster prevention in the Guanshan River Basin and showed that the risk assessment for the flash flood disasters must be considered when planning the regional economic development, otherwise, development problems may be encountered.

Author Contributions: Conceptualization, N.C. and Y.Z. (Yanjun Zhang); methodology, N.C. and Y.Z. (Yanjun Zhang); software, N.C.; validation, N.C. and J.W.; formal analysis, W.D.; investigation, N.C. and Y.Z. (Yixuan Zou); resources, N.C. and J. W; data curation, N.C. and X.X.; writing-original draft preparation, N.C.; writing-review and editing, N.C. and Y.Z. (Yanjun Zhang); visualization, N.C.; supervision, Y.Z. (Yanjun Zhang); project administration, Y.Z. (Yanjun Zhang); funding acquisition, Y.Z. (Yanjun Zhang). All authors have read and agreed to the published version of the manuscript.

Funding: This research was funded by the National Key Research and Development Plan Project of China (No. 2017YFC1502503) and Major Program of National Natural Science Foundation of China (No. 41790431).

Conflicts of Interest: The authors declare no conflict of interest.

\section{References}

1. Oruonye, E.D. Socio-economic impact assessment of flash flood in Jalingo metropolis, Taraba State, Nigeria. Int. J. Environ. Sci. 2012, 1, 135-140.

2. Saber, M.; Hamaguchi, T.; Kojiri, T.; Tanaka, K. Flash flooding simulation using hydrological modeling of wadi basins at nile river based on satellite remote sensing data. Annu. Dis. Prev. Res. Inst. Kyoto Univ. 2010. Available online: https://repository.kulib.kyoto-u.ac.jp/dspace/handle/2433/129361 (accessed on 11 June 2020). 
3. Sanyal, J.; Lu, X. Remote sensing and GIS-based flood vulnerability assessment of human settlements: A case study of Gangetic West Bengal, India. Hydrol. Process. 2005, 19, 3699-3716. [CrossRef]

4. Delrieu, G.; Nicol, J.; Yates, E.; Kirstetter, P.-E.; Creutin, J.-D.; Anquetin, S.; Obled, C.; Saulnier, G.-M.; Ducrocq, V.; Gaume, E.; et al. The Catastrophic Flash-Flood Event of 8-9 September 2002 in the Gard Region, France: A First Case Study for the Cévennes-Vivarais Mediterranean Hydrometeorological Observatory. J. Hydrometeorol. 2005, 6, 34-52. [CrossRef]

5. Špitalar, M.; Gourley, J.J.; Lutoff, C.; Kirstetter, P.-E.; Brilly, M.; Carr, N. Analysis of flash flood parameters and human impacts in the US from 2006 to 2012. J. Hydrol. 2014, 519, 863-870. [CrossRef]

6. Ruin, I.; Creutin, J.-D.; Anquetin, S.; Lutoff, C. Human exposure to flash floods-Relation between flood parameters and human vulnerability during a storm of September 2002 in Southern France. J. Hydrol. 2008, 361, 199-213. [CrossRef]

7. Fengqing, J.; Cheng, Z.; Guijin, M.; Ruji, H.; Qingxia, M. Magnification of Flood Disasters and its Relation to Regional Precipitation and Local Human Activities since the 1980s in Xinjiang, Northwestern China. Nat. Hazards 2005, 36, 307-330. [CrossRef]

8. Balica, S.F.; Douben, N.; Wright, N. Flood vulnerability indices at varying spatial scales. Water Sci. Technol. 2009, 60, 2571-2580. [CrossRef]

9. Forkuo, E.K. Flood hazard mapping using Aster image data with GIS. Int. J. Geomat. Geosci. 2011, 1, 932-950.

10. Garrote, J.; Alvarenga, F.; Diez-Herrero, A. Quantification of flash flood economic risk using ultra-detailed stage-damage functions and 2-D hydraulic models. J. Hydrol. 2016, 541, 611-625. [CrossRef]

11. Vojtek, M.; Vojteková, J. Flood hazard and flood risk assessment at the local spatial scale: A case study. Geomat. Nat. Hazards Risk 2016, 7, 1973-1992. [CrossRef]

12. Huang, Y. Comparison and Application of Hydrological Models in Mountain Flood Simulation. J. Water Resour. Res. 2019, 8, 33-43. [CrossRef]

13. Danjiangkou City Suffered a Heavy Rain Disaster. Available online: http://www.hbdjk.com/html/2012-08/ 76094.html (accessed on 15 August 2018).

14. A Catastrophic Flood happened in Liuliping Town and Guanshan Town, Shiyan City, Hubei Province, China, on 6 August 2012. Available online: http://blog.sina.com.cn/s/blog_5e43f42901012a91.html (accessed on 15 August 2018).

15. Uysal, M.M.; Toprak, A.; Polat, N. DEM generation with UAV Photogrammetry and accuracy analysis in Sahitler hill. Measurement 2015, 73, 539-543. [CrossRef]

16. National Bureau of Statistics of China. China Statistical Yearbook (2003-2018); China Statistics Press: Beijing, China, 2006. (In Chinese)

17. Ambroise, B.; Beven, K.; Freer, J. Toward a Generalization of the TOPMODEL Concepts: Topographic Indices of Hydrological Similarity. Water Resour. Res. 1996, 32, 2135-2145. [CrossRef]

18. Steers, J.A.; Peel, R.; Chisholm, M.; Haggett, P. Processes in Physical and Human Geography. Geogr. J. 1976, 142, 539. [CrossRef]

19. Beven, K.J.; Kirkby, M.J. A physically based, variable contributing area model of basin hydrology/Un modèle à base physique de zone d'appel variable de l'hydrologie du bassin versant. Hydrol. Sci. Bull. 1979, 24, 43-69. [CrossRef]

20. O’Brien, J. FLO-2D Reference Manual, Version 2009. FLO-2D Official Website. Available online: http: //www.flo-2d.com (accessed on 6 June 2011).

21. Hübl, J.; Steinwendtner, H. Two-dimensional simulation of two viscous debris flows in Austria. Phys. Chem. Earth Part C 2001, 26, 639-644. [CrossRef]

22. Boniello, M.A.; Calligaris, C.; Lapasin, R.; Zini, L. Rheological investigation and simulation of a debris-flow event in the Fella watershed. Nat. Hazards Earth Syst. Sci. 2010, 10, 989-997. [CrossRef]

23. Zonensein, J.; Miguez, M.G.; De Magalhães, L.P.C. Flood Risk Index as An Urban Management Tool, 11th ed.; ICUD: Edinburgh, Scotland, 2008.

24. Nasiri, H.; Shahmohammadi-Kalalagh, S. Flood vulnerability index as a knowledge base for flood risk assessment in urban area. J. Novel Appl. Sci. 2013, 2, 269-272.

25. Zhang, D.-W.; Quan, J.; Zhang, H.-B.; Wang, F.; Wang, H.; He, X.-Y. Flash flood hazard mapping: A pilot case study in Xiapu River Basin, China. Water Sci. Eng. 2015, 8, 195-204. [CrossRef]

26. Beffa, C. Two-Dimensional Modelling of Flood Hazards in Urban Areas, 3rd ed.; Brandenbur University of Technology: Berlin, Germany, 1998. 
27. FLO-2D Software, Inc. FLO-2D Mapper Manual Pro, Version 2017. FLO-2D Official Website. Available online: http://www.flo-2d.com (accessed on 25 November 2018).

28. Loat, R.; Petrascheck, A. Prise en compte des dangers dus aux crues dans le cadre des activités de l'aménagement du territoire. Recommandations, dangers naturels. Office fédéral de l'économie des eaux (OFEE), Office fédéral de l'aménagement du territoire (OFAT), Office fédéral de l'environnement (OFEFP), des forêts et du paysage. 1997. Available online: http://www.planat.ch/de/suche/?tx_indexedsearch\% 5Bsword \%5D=Loat\%2C+R.\%3B+Petrascheck\%2C+A (accessed on 28 March 2019).

29. National Flash Flood Disaster Prevention Project Team of China. Technical Requirements for Analysis and Evaluation of Flash Flood Disasters. Douding Construction Network. Available online: http://jz.docin.com/ p-1237230452.html.2014-08 (accessed on 23 April 2019).

30. Wen, J.B. Regulations on the Prevention and Control of Geological Hazards in China. Bull. People's Gov. Henan Prov. 2004, 7, 2-56.

31. Zhan, D.J.; Xu, X.Y.; Chen, Y.F. Engineering Hydrology, 4th ed.; China Water \& Power Press: Tianjin, China, 2010.

32. Sun, J.C.; Zhang, J.Y.; Wang, J. Standard for Hydrological Information and Hydrological Forecasting; Chinese Standard; Chinese Ministry of Water Resources: Beijing, China, 2008.

33. Guo, J. Hydrological Model of Guanshan River Basin Based on Mixed Runoff Model. Master's Thesis, Wuhan University, Wuhan, China, 2019.

34. Campling, P.; Gobin, A.; Beven, K.; Feyen, J. Rainfall-runoff modelling of a humid tropical catchment: The TOPMODEL approach. Hydrol. Process. 2002, 16, 231-253. [CrossRef]

35. Zhao, X. Hydraulics, 1st ed.; China Electric Power Press: Beijing, China, 2009.

36. FLO-2D Software, Inc. Data Input Manual PRO, Version 2016. FLO-2D Official Website. Available online: http://www.flo-2d.com (accessed on 25 November 2018).

37. Haltas, I.; Tayfur, G.; Elçi, Ş. Two-dimensional numerical modeling of flood wave propagation in an urban area due to Ürkmez dam-break, İzmir, Turkey. Nat. Hazards 2016, 81, 2103-2119. [CrossRef]

38. Apel, H.; Aronica, G.T.; Kreibich, H.; Thieken, A. Flood risk analyses-how detailed do we need to be? Nat. Hazards 2008, 49, 79-98. [CrossRef]

39. Hsu, S.M.; Chiou, L.B.; Lin, G.-F.; Chao, C.H.; Wen, H.Y.; Ku, C.-Y. Applications of simulation technique on debris-flow hazard zone delineation: A case study in Hualien County, Taiwan. Nat. Hazards Earth Syst. Sci. 2010, 10, 535-545. [CrossRef]

40. Calligaris, C.; Boniello, M.A.; Zini, L. Debris flow modelling in Julian Alps using FLO-2D. Debris Flow 08 2008, 60, 81-88. [CrossRef]

41. Kourgialas, N.; Karatzas, G.P. Flood management and a GIS modelling method to assess flood-hazard areas-A case study. Hydrol. Sci. J. 2011, 56, 212-225. [CrossRef]

42. Merz, B.; Elmer, F.; Thieken, A. Significance of "high probability/low damage" versus "low probability/high damage" flood events. Nat. Hazards Earth Syst. Sci. 2009, 9, 1033-1046. [CrossRef]

43. Nadal, N.C.; Zapata, R.E.; Pagán, I.; Lopez, R.; Agudelo, J. Building Damage due to Riverine and Coastal Floods. J. Water Resour. Plan. Manag. 2010, 136, 327-336. [CrossRef]

(C) 2020 by the authors. Licensee MDPI, Basel, Switzerland. This article is an open access article distributed under the terms and conditions of the Creative Commons Attribution (CC BY) license (http://creativecommons.org/licenses/by/4.0/). 